\title{
THE EFFECT OF CHICKEN SKIN GELATIN AND WHEY PROTEIN INTERACTIONS ON RHEOLOGICAL AND THERMAL PROPERTIES
}

3

4

6

7

8

9

10

11

12

13

\author{
Norizah Mhd Sarbon ${ }^{1,2}$, Farah Badii ${ }^{1}$ and Nazlin K Howell ${ }^{1 *}$
}

1. Faculty of Health and Medical Sciences, University of Surrey, Guildford, Surrey, GU2 7XH, UK.

2. School of Food Science and Technology, Universiti Malaysia Terengganu, 21030, Kuala Terengganu, Terengganu, Malaysia.

*Corresponding author. Tel.: 00441483686448

Fax: 00441483686401

E-mail address: $\underline{\text { N.Howell@ } @ \text { surrev.ac.uk }}$ 


\section{Abstract}

Physical, thermal and microstructural properties of whey protein isolate (WPI) and chicken skin gelatin mixtures were investigated. This is a first study on the compatibility of an unutilised gelatin source from chicken skin with a well-characterised food protein. The physical-chemical and rheological properties of chicken skin gelatin alone, were reported in our previous paper Sarbon, Badii \& Howell, (2013). Preparation and characterisation of chicken skin gelatin as an alternative to mammalian gelatin. Food Hydrocolloids 30, 143-151. In the present study, small deformation rheology indicated that combinations of gelatin $(3,5$ and $10 \%$ ) and $10 \%$ whey protein (WPI) in distilled water resulted in high elastic modulus (G') values of 1860, 23914 and $20145 \mathrm{~Pa}$, respectively, compared with $120 \mathrm{~Pa}$ for $10 \%$ WPI alone, due to synergistic interaction. Frequency sweeps showed increased strength of networks in gels containing higher concentrations of gelatin in WPI/gelatin mixtures. Gelatin gels were more stable and stronger than $10 \%(\mathrm{w} / \mathrm{w})$ whey protein gels and did not exhibit frequency dependence for $\mathrm{G}^{\prime}$ and $\mathrm{G}^{\prime \prime}$, giving low $\tan \delta\left(\mathrm{G}^{\prime \prime} / \mathrm{G}^{\prime}\right)$ values of $<0.1$. Large deformation gel strength values of all samples increased significantly $(\mathrm{p}<0.05)$ with increasing gelatin concentration and were greater at each concentration compared to gelatin alone. Differential scanning calorimetry transition temperature $(\mathrm{Tm})$ and enthalpy change $(\Delta \mathrm{H})$ of gelatin and whey protein mixed in the ratios 3:10, 5:10 and 10:10 (w/w) confirmed the reversibility of the gelatin transition on heating to $90 \mathrm{oC}$ and cooling to $10{ }^{\circ} \mathrm{C}$ and irreversible denaturation of WPI on heating. The addition of 3, 5 or $10 \%$ gelatin to whey protein increased the Tm of whey protein and decreased the Tm of gelatin. However, the presence of $10 \%(\mathrm{w} / \mathrm{w}) \mathrm{WPI}$ significantly increased the $\Delta \mathrm{H}$ values to $0.62,1.34$ and $2.20 \mathrm{~J} / \mathrm{g}$ for 3,5 and $10 \%(\mathrm{w} / \mathrm{w}$ ) gelatin solutions respectively, indicating whey-gelatin interaction. Chicken skin gelatin gels exhibited a fine network of uniform particles whereas whey protein gels comprised aggregates. Differences in structure and molecular size led to phase separation of the mixed gels. The above properties of an underutilized non-mammalian source of gelatin may lead to novel applications in the food industry.

Keywords: Chicken skin gelatin, whey protein isolate, interactions, rheology, gel strength, differential scanning calorimetry, microstructure. 


\section{INTRODUCTION}

Gelatin is obtained by the denaturation of the triple helix of collagen. In solution at moderate temperature above $40{ }^{\circ} \mathrm{C}$, gelatin exists as flexible, disordered coils, which associate into triple helices, similar to native collagen. Gelatin gels on cooling to below 30 ${ }^{\circ} \mathrm{C}$ resulting in a progressive increase in gel strength (Joly-Duhamel, Hellio \& Djabourov, 2002; Stainsby, 1977). However, gelatin melts due to the dissociation of triple helices as the temperature is raised above $35{ }^{\circ} \mathrm{C}$ (Fitzsimons et al., 2008). As gelatin is often used to stabilise dairy products such as mousse, ice cream, flavoured yoghurts and drinks, its properties in the presence of well-characterised whey proteins was examined.

Whey is an abundant and readily available by-product of the cheese industry which was once regarded as waste material, and was fed to livestock or discarded. Whey is now considered to be a valuable source of proteins and is widely used as a food ingredient (Bottomley et al., 1990; Mulvihill \& Ennis, 2003) to improve functional characteristics including gelation, foaming and emulsification as well as nutritional properties (Burrington, 1998; Huffman, 1996; de Wit, 1998). Networks formed during whey protein isolate (WPI) gelation contribute to texture, water holding capacity, and appearance of the gel. Protein gels are grouped as particulate, fine-stranded, or mixed networks; and $\mathrm{pH}$, solutes, and gelation kinetics determine the type of gel matrix formed.

Biopolymer mixtures have been extensively studied over the last 30 years as the variety of physical, chemical and textural properties can be manipulated to give novel products. Protein-protein interactions are investigated to acquire knowledge of structurefunction relationships; optimise product constituents; improve food quality and formulate new products. Howell (1994) identified three ways in which proteins can be characterised in terms of their interaction with other biopolymers namely synergistic interactions, aggregation and phase separation which may lead to interesting and technologically useful applications. Synergistic interactions can enhance gelation properties over and above those of the individual protein used on its own and have been observed in egg albumen-plasma proteins mixtures (Howell \& Lawrie, 1984) and whey-egg albumen mixtures (Ngarize et al., 2005) where small globular proteins produced compatible gel structures. However, some proteins can aggregate due to electrostatic interactions, for example, between negatively charged $\alpha$ - lactalbumin and $\beta$-lactoglobulin and positively charged lysozyme (Howell, 
1994). In most cases, mixing two or more biopolymers results in phase separation, which can be associative (the first phase being enriched in both polymers, the second one in the solvent) or segregative (each phase being enriched with one of the two biopolymers) (Tolstoguzov, 1992, 1995; Doublier et al., 2000). Phase separation has been observed in binary protein-protein mixed gels such as milk-soy proteins (Chronakis \& Kasapis, 1993), gelatin/whey (Walkenstrom \& Hermansson, 1994), soya/whey (Comfort \& Howell, 2002) and meat/soluble wheat protein (Comfort \& Howell, 2003). In these systems the two biopolymers formed independent phase- separated networks where individual polymers were identified by viscoelastic measurements and microscopy. Similarly, phase separation has been reported extensively in protein- polysaccharide systems including agar/gelatin (Clark et al., 1983), gelatin/maltodextrin (Kasapis, et al., 1993; Loren and Hermansson, 2000; Plucknett et al., 2000; Loren et al., 2001; Norton and Frith, 2001; Butler and Heppenstall-Butler, 2003), gellan/gelatin (Papageorgiou et al., 1994), agar/ BSA (Clark, et al., 1982), gelatin/pectin (Gilsenan et al., 2003), gelatin/ alginate (Tolstoguzov,1995; Doume' che, et al., 2007) with a view to their application in products including low fat products where these biopolymers may exist together.

In terms of whey-mammalian gelatin applications, a study by Brink et al., (2007) showed that the mixture of whey protein isolate (WPI) gels with varying amounts of gelatin affected the structural and mechanical properties of whey protein isolate/gelatin gels at the macro and micro levels, although the difference between micro and macro strain decreased with increasing gelatin concentration. Moreover, the effect of using whey protein $\beta$ lactoglobulin with different degrees of denaturation $(0 \%, 20 \%, 40 \%$ and $60 \%)$, as a stabilizing agent in the formation of aerated gelatin gels, using high intensity ultrasound as a novel method to incorporate bubbles in model foods in order to create unique rheological properties, was investigated by Zúñiga et al., (2011)

We isolated chicken skin gelatin and recently reported its chemical, physical rheological properties for the first time (Sarbon, Badii and Howell, 2013). The aim of the present study was to investigate the compatibility of the novel chicken skin gelatin and well-characterised whey proteins in mixed gel systems. Melting and gelling characteristics and the stability of chicken gelatin and whey protein mixed gels were investigated by large and small deformation rheology, thermodynamic properties by DSC and microstructure by phase contrast microscopy. 


\section{MATERIAL AND METHODS}

\subsection{Materials}

A commercial whey protein isolate (WPI) powder containing approximately 93 $\%$ protein (Bipro) was provided by Davisco Foods International, Le Sueur, MN 56058, USA. The gelatin sample was extracted from chicken skin as described in a previous paper (Sarbon, Badii \& Howell, 2013) and had a bloom strength of $355 \pm 1.48 \mathrm{~g}$, The protein content of gelatin as determined by Kjeldhal analysis was $81 \%$, ( $\mathrm{N}$ x 5.55) and the ash content was $0.37 \%(\mathrm{AOAC}, 2006)$. All solutions were prepared in distilled water and all chemicals and reagents used were analytical grade.

\subsection{Methods}

\subsubsection{Chicken skin preparation}

Frozen chicken skin waste, produced from chicken filleting was provided by a local supermarket, Guildford. The skins were thawed in a cold room $\left(4-5{ }^{\circ} \mathrm{C}\right)$ overnight. After thoroughly rinsing in water to remove impurities, the skins were cut into $2-3 \mathrm{~cm}$ pieces and freeze-dried. Completely dry skins were ground before being defatted extensively using the Soxhlet method (AOAC, 2006).

\subsubsection{Gelatin extraction}

Gelatin was extracted from chicken skin according to the method of Badii \& Howell (2006) with a slight modification and as detailed by Sarbon, Badii \& Howell (2013). Briefly, $14 \mathrm{~g}$ defatted dried chicken skin was mixed with $200 \mathrm{ml} 0.15 \% \mathrm{w} / \mathrm{v}$ sodium hydroxide at $22{ }^{\circ} \mathrm{C}$ for $40 \mathrm{~min}$ and centrifuged at $3500 \mathrm{x} \mathrm{g}$ for $10 \mathrm{~min}$. The alkaline treated pellets were rinsed repeatedly with distilled water to remove non-collagen proteins and pigments. The pellets were treated with $200 \mathrm{ml} 0.15 \%(\mathrm{v} / \mathrm{v})$ sulphuric acid at $22{ }^{\mathrm{O}} \mathrm{C}$ for $40 \mathrm{~min}$ and centrifuged at $3500 \mathrm{x} \mathrm{g}$ for $10 \mathrm{~min}$ followed by treatment with $200 \mathrm{ml}$ of $0.7 \%$ $(\mathrm{w} / \mathrm{v})$ citric acid solution and centrifugation. Each treatment was repeated three times followed by a final extraction with distilled water at $45{ }^{\circ} \mathrm{C}$ overnight. The mixture was filtered and deionised on an Amberlite mixed bed resin (M B-6113). The $\mathrm{pH}$ was adjusted to 6.0 with $0.1 \mathrm{M} \mathrm{sulphuric}$ acid prior to freeze-drying. The resultant chicken 
skin gelatin powder, characterised for the first time for chemical and rheological properties by Sarbon, Badii \& Howell (2013), was used to study the rheological, thermodynamic and microstructural properties in combination with commercial whey protein isolate as described below.

\subsubsection{Sample preparation}

The gelatin and whey protein isolate (WPI) solutions were prepared separately in distilled water. WPI was dissolved by gentle stirring for $1 \mathrm{~h}$ at $22{ }^{\circ} \mathrm{C}$. Gelatin powder prepared as above, was dispersed in distilled water and allowed to swell before it was heated to $45{ }^{\circ} \mathrm{C}$, i.e. above the melting temperature. Individual solutions of WPI and chicken skin gelatin were prepared at double the required concentration and equal weights were mixed at $45{ }^{\circ} \mathrm{C}$ for 15 min to produce the final experimental samples, with $\mathrm{pH}$ adjusted to 7.0. Homogenous mixed solutions were prepared at $40{ }^{\circ} \mathrm{C}$ using a constant whey protein concentration of $10 \%(\mathrm{w} / \mathrm{w})$ and with a varying concentration of gelatin within the range 3$10 \%(\mathrm{w} / \mathrm{w})$. Samples with different ratios were prepared by mixing equal volumes of gelatin $(6,10$ or $20 \% \mathrm{w} / \mathrm{w}$ in distilled water) and whey $(20 \% \mathrm{w} / \mathrm{w}$ in distilled water) to obtain gelatin: WPI ratio of 3:10, 5:10 and 10:10. This sample preparation was used for all analyses conducted.

\subsubsection{Differential scanning calorimetry (DSC)}

Thermal properties of gelatin were investigated using a Micro DSC VII calorimeter (Setaram, Lyon, France). Protein samples and deionised water as reference (500 mg) were weighed into stainless steel containers and scanned from 8 to $90{ }^{\circ} \mathrm{C}$ at a heating rate 0.5 ${ }^{\circ} \mathrm{C} / \mathrm{min}$. The sample was cooled and immediately heated for the first time (cycle 1). The same sample was heated again (cycle 2), to test the reversibility of the transition for the gelatin sample. Samples were tested using 3, 5 and $10 \%(\mathrm{w} / \mathrm{v})$ protein concentrations. Endothermic peaks were observed and the helix-coil transition temperature $\left(T_{m}\right)$ was measured as the tip of the peak. The enthalpy change $(\Delta H)$ which is the total energy required for denaturing the protein, was obtained after base lining and by integrating the area under the peak (Setaram DSC software and handbook). The results were an average of three determinations.

\subsubsection{Rheological properties}




\subsubsection{Large deformation test}

Protein samples $(3,5$ and $10 \%(\mathrm{w} / \mathrm{w})$ gelatin with $10 \%(\mathrm{w} / \mathrm{w})$ whey in distilled water were poured into stainless steel tubes (30 mm diameter and $50 \mathrm{~mm}$ long) and sealed at each end with rubber stoppers (Badii and Howell, 2006) The upper stopper had a small hole for pressure equilibration. The tubes containing samples were heated accurately in a water bath at $90{ }^{\circ} \mathrm{C}$ for $30 \mathrm{~min}$ to denature the whey proteins and promote aggregation and network formation. The tubes were cooled under running water and left at room temperature for $30 \mathrm{~min}$ before ageing and setting overnight $(17 \mathrm{~h})$ at $4{ }^{\circ} \mathrm{C}$ prior to testing.

The gels were removed from the tubes, cut precisely to a length of $15 \mathrm{~mm}$, and placed centrally under a cylindrical plunger (diameter $43 \mathrm{~mm}$ ) on a TA-XT2 texture analyzer (Stable Microsystem, Godalming, UK) and compressed at $0.2 \mathrm{~mm} / \mathrm{sec}$ through 10 $\mathrm{mm}$ to a final size of $5 \mathrm{~mm}$. The force $(\mathrm{g})$ at maximum compression $(10 \mathrm{~mm})$ (gel strength) was obtained, for at least five replicate gels (not broken), reflecting the strength of the gels.

\subsubsection{Dynamic oscillatory measurements}

\section{Temperature sweep}

Dynamic oscillatory measurements on temperature and frequency sweeps of gelatin and WPI mixtures were performed on a Rheometrics (Leatherhead, Surrey, UK) controlled stress 200 rheometer using $40 \mathrm{~mm}$ parallel plate geometry with a $0.3 \mathrm{~mm}$ gap. The sample was applied and silicone oil (Sigma cat. no 14615-3) was spread over the outer edge of the sample to prevent evaporation during heating. The gelation properties and melting temperature of the protein samples and mixtures were determined by a temperature sweep test using $0.1 \mathrm{~Pa}$ stress and $1 \mathrm{rad} / \mathrm{s}$ frequency, which was a compromise between measuring so quickly that entanglements are included or so slowly that not enough data are generated. The applied stress was varied to keep the strain at about $1 \%$ in order to make the measurements in the linear viscoelastic region (Badii \& Howell, 2006; Sarbon, Badii \& Howell, 2013. The samples were heated on a Peltier plate from 20 to $90{ }^{\circ} \mathrm{C}$ and cooled back to $20{ }^{\circ} \mathrm{C}$ at a scanning rate of $2{ }^{\circ} \mathrm{C} / \mathrm{min}$. The gelation temperature of whey protein was defined as the temperature at which the elastic modulus $\left(G^{\prime}\right)$ increased above that of the $G^{\prime}$ ' (the $\mathrm{G}^{\prime} / \mathrm{G}^{\prime \prime}$ cross over point), as shown from the actual readings on the rheometer (not an estimate from the figure heating and cooling curves). Melting of gelatin occurred when the elastic modulus $\left(G^{\prime}\right)$ began to decrease and loss modulus $\left(G^{\prime \prime}\right)$ increased in value. Changes 
in the elastic or storage modulus $\left(G^{\prime}\right)$ and loss modulus $\left(G^{\prime \prime}\right)$ were determined as a function of temperature and were recorded in triplicate.

\section{Frequency sweep}

To assess the cross-linking behaviour of gelatin, a dynamic frequency sweep was performed at $10{ }^{\circ} \mathrm{C}$ with stress held at $319.7 \mathrm{~Pa}$ and frequency oscillated from $0.1-100 \mathrm{rad} / \mathrm{s}$, within the identified linear viscoelastic region. Changes in elastic $\left(\mathrm{G}^{\prime}\right)$ and loss modulus $\left(\mathrm{G}^{\prime \prime}\right)$ as a function of frequency were recorded for mixtures comprising 3, 5 and $10 \%(\mathrm{w} / \mathrm{v})$ of gelatin and $10 \%(\mathrm{w} / \mathrm{v})$ of whey protein in triplicate.

\subsubsection{Phase contrast microscopy}

Phase contrast microscopy was used to study the structure of the gels as described by Badii \& Howell (2006). Equal volumes of gelatin (6, 10 and $20 \%$ w/w in distilled water) and whey $(20 \% \mathrm{w} / \mathrm{w}$ in distilled water) were mixed. A drop of each mixture was placed on a microscope slide, covered with a cover slip and heated over a boiling water bath followed by cooling to $20{ }^{\circ} \mathrm{C}$. Micrographs were taken with a phase contrast Leitz microscope with a Wild MPS 05 camera system and an exposure meter set on camera factor 0.32 using x100 magnification.

\subsection{STATISTICAL ANALYSIS}

One-way analysis of variance (ANOVA) was performed by using the SPSS package version 16. Differences between pairs of means were assessed on the basis of confidence intervals using a post-hoc test. The level of significance was considered at $p<0.05$.

\section{RESULTS AND DISCUSSION}

\subsection{Differential scanning calorimetry (DSC) of gelatin and whey protein mixtures}

The denaturation temperature and enthalpy change in the mixed protein systems were determined by DSC. DSC thermograms of the $10 \%(\mathrm{w} / \mathrm{v})$ chicken skin gelatin indicated a 
reversible gel as a single transition appeared in both the heating cycles 1 and 2 (Figure 1a). Minor changes in thermal denaturation $\left(T_{m}\right)$ and enthalpy change or transition enthalpy $(\Delta H)$ on a second heating scan confirmed that gelatin undergoes a helix to coil transition on heating and refolds on cooling, recovering most of the helical structure (McLachlan \& Karn, 1982). In contrast, whey protein (10\%, w/v), showed a single endothermic peak (Figure 1b) in the first scan; however after cooling and heating for the second time (cycle 2) produced a flat line showing that the whey protein transition was not reversible as the protein was denatured in cycle 1 . Globular whey protein on heating to $90{ }^{\circ} \mathrm{C}$ resulted in partial unfolding of the molecule into a molten globule followed by aggregation involving covalent and non-covalent bonds to produce an irreversibly denatured protein (Comfort and Howell, 2002).

Similarly, in Figure 2 the DSC thermogram of a mixture of gelatin (10\%) and whey protein $(10 \%)$ both w/w in distilled water show that the melting profiles of the two different proteins, reversible gelatin and non-reversible whey protein, were retained in the mixture. The melting temperature of the gelatin, as heat flow, corresponds to the energy absorbed by gelatin to achieve the helix-to-coil conformation through melting of the junction zones (Cheow et al., 2007). The denaturation temperature $\left(T_{m}\right)$ peak of gelatin was recorded for both cycles in gelatin-whey protein mixtures. Gelatin had a broad shoulder compared to whey proteins which indicates that gelatin melted over a wide temperature range apparently due to the structural heterogeneity of gelatin. Figure 3 illustrates the DSC thermograms for the $1^{\mathrm{st}}$ heating cycle $\left(8-90^{\circ} \mathrm{C}\right)$ of chicken skin gelatin: whey protein mixtures (3\%:10\%, 5\%:10\% and 10\%:10\% in distilled water) respectively. The denaturation temperature $\left(T_{m},{ }^{\circ} \mathrm{C}\right)$ and enthalpy change $(\Delta H, \mathrm{~J} / \mathrm{g})$ values of each endothermic peak versus gelatin/whey mass ratios are shown in Tables 1 and 2 respectively.

Table 1 shows the denaturation temperature $\left(T_{m}\right)$ of chicken skin gelatin at different concentrations with and without the addition of $10 \%(\mathrm{w} / \mathrm{w})$ WPI during both the $1^{\text {st }}$ and $2^{\text {nd }}$ scanning cycles. During the first cycle, 3, 5 and $10 \%(\mathrm{w} / \mathrm{w})$ gelatin solutions in distilled water denatured at $T_{m}$ of $30.99,30.73$ and $31.16{ }^{\circ} \mathrm{C}$ respectively which were not significantly different ( $\mathrm{p}>0.05$ ). However, the addition of $10 \%$ (w/w) WPI to 3,5 and $10 \%$ (w/w) gelatin resulted in a slight decrease in the $T_{m}$ of the mixtures to $28.79,28.58$ and $27.87{ }^{\circ} \mathrm{C}$ respectively; however, these values were also not significantly different ( $\left.>0.05\right)$.. This may be explained by the fact that the formation of intramolecular crosslinks, which 
would inhibit the formation of collagen-like structure, is favoured over intermolecular ones in dilute solutions (Sakamoto et al., 1994). Compared to the first cycle, the second cycle showed that the $T_{m}$ of gelatin shifted significantly $(\mathrm{p}<0.05)$ to a lower temperature in the absence and presence of $10 \%(\mathrm{w} / \mathrm{w})$ WPI at all concentrations. In addition, the $T_{m}$ of WPI increased significantly i.e. from 67.65 to $74.93,75.94$ and $77.04{ }^{\circ} \mathrm{C}$ in the presence of $0,3,5$ and $10 \%(\mathrm{w} / \mathrm{w})$ gelatin solutions respectively. These results indicate an interaction between the whey and gelatin proteins as the presence of the whey protein was more important in determining the $\mathrm{T} m$ rather than the increasing gelatin concentration. Gelatin does not contain disulphide bonds but has hydrophobic and charged amono acids that would contribute to non-covalent hydrogen, hydrophobic, electrostatic interactions (Sarbon, Badii \& Howell, 2013).

The enthalpy change $(\Delta H)$ of chicken skin gelatin, at different concentrations with and without the addition of $10 \%(\mathrm{w} / \mathrm{w})$ WPI, is presented in Table 2. The enthalpy change, $\Delta H$ (the area under the peak, between the curve and the baseline)) provides information on the energy required to denature the proteins which is related to the concentration and the number of junction zones (Michon et al., 1997). The enthalpy change $(\Delta H)$ of chicken gelatin solutions at 3,5 and $10 \%(\mathrm{w} / \mathrm{w})$ in the absence and presence of $10 \%(\mathrm{w} / \mathrm{w})$ WPI during both first and second heating cycle scans increased with increased concentration. During the first heating cycle, $\Delta H$ values of 3, 5 and $10 \%(\mathrm{w} / \mathrm{w})$ gelatin solutions in distilled water were $0.36,0.50$ and $0.88 \mathrm{~J} / \mathrm{g}$ respectively and were significantly different $(\mathrm{p}<0.05)$. This is expected as more protein was denatured at the higher concentration. Moreover, the addition of $10 \%$ (w/w) WPI to the different gelatin solutions also substantially increased the $\Delta H$ to $0.62,1.34$ and $2.20 \mathrm{~J} / \mathrm{g}$ for 3,5 and $10 \%$ (w/w) gelatin respectively; these values were also significantly different $(\mathrm{p}<0.05)$ between concentrations. These results also indicate interaction between the whey and gelatin proteins with higher than expected values.

During the second heating cycle, the $\Delta H$ values of gelatin solutions without $10 \%$ (w/w) WPI increased with increasing gelatin concentration and the values were surprisingly higher $(0.48,1.03$ and $2.06 \mathrm{~J} / \mathrm{g}$ for 3,5 and $10 \%$ (w/w) gelatin respectively) than the first cycle; the values were significantly different $(\mathrm{p}<0.05)$. Although the $\Delta H$ values of second cycle with added WPI also increased with increased gelatin concentrations $(0.54,1.27$ and $2.04 \mathrm{~J} / \mathrm{g}$ at 3,5 and $10 \%(\mathrm{w} / \mathrm{w})$ gelatin respectively, these values were lower than those 
observed for the first cycle. However, both 3 and $5 \%$ gelatin/whey mixture (second cycle) had significantly different $\Delta H$ values in the presence and absence of $10 \%$ whey; there was no such significant difference $(\mathrm{p}>0.05)$ for $10 \%$ gelatin/whey mixture. An increase in the $\Delta H$ values suggests that the protein changed into a more compact conformation or associated to form a complex structure with higher thermal stability (Badii \& Howell, 2006) and an increased number and strength of the cross-linkages of the network microstructure (Jiang et al., 2010).

\subsection{Large deformation tests}

The effect on gel strength of adding gelatin (3, 5 and $10 \% \mathrm{w} / \mathrm{w})$ to $10 \%(\mathrm{w} / \mathrm{w})$ whey proteins in distilled water are shown in Table 3. The gel strength of all samples was significantly increased $(\mathrm{p}<0.05)$ with increasing gelatin concentration, due to the higher protein concentration, and was greater at each concentration when compared to the sample that contained gelatin alone. The gel strength (at maximum compression of $10 \mathrm{~mm}$ ) of the gelatin: whey gels mixed in the ratio10:0, 3:10, 5:10 and 10:10 were 241, 459, 578 and 897 $\mathrm{g}$ and the areas under the curve were 4,890, 8,888, 12,012 and 17,940 $\mathrm{g}$ respectively (Table $3)$. The increase in the gel strength was due to the formation of intermolecular crosslinks of collagen triple helical structures in the mixtures during cooling and ageing (17 h) and the fact that the rigidity modulus of gelatin increased with time after setting (Stainsby, 1977).

These results may be explained by the differences in pore size and strand characteristics between gelatin and whey proteins as shown by the microstructure results. Whey proteins are reported to form aggregates and gels that have a large pore size that contribute to a weak structure (Standing et al., 1993). In contrast, gelatin contains fine strands in its network which strengthens the gels. Therefore, an increase in gelatin concentration in the mixtures resulted in increased gel strength. As there was no gel formation observed for $10 \%(\mathrm{w} / \mathrm{w})$ whey proteins on their own in the tubes, under the same conditions of these experiments, gelatin was essential for enhancing the gel strength of the mixtures via association between whey proteins and gelatin chains. Gelatin $10 \%(w / w)$ had a gel strength value of $241 \mathrm{~g}$ on its own and $10 \%$ whey protein in distilled water did not gel. However, the mixture of $10 \%$ gelatin and $10 \%$ whey protein was about $3 \mathrm{x}$ greater at $897 \mathrm{~g}$, thus indicating synergistic interaction and enhancement of the gelling properties of both gelatin and whey proteins. 


\subsection{Dynamic oscillatory measurements}

401

\subsubsection{Temperature sweeps}

\section{Mixed gel behaviour}

The development of the storage modulus $\left(\mathrm{G}^{\prime}\right)$ during gel formation of whey gel $(10 \%$, $\mathrm{w} / \mathrm{w})$, gelatin $(3 \%, \mathrm{w} / \mathrm{w})$ and a mixed gel $(3 \%(\mathrm{w} / \mathrm{w})$ gelatin $+10 \%(\mathrm{w} / \mathrm{w})$ whey) are shown as heating and cooling curves in Figures $4 \mathrm{a}, \mathrm{b}$ and $\mathrm{c}$ respectively. The gelation temperature of WPI (Figure 4c) in the mixed gel was $83.65{ }^{\circ} \mathrm{C}$. The lower gelling temperature of WPI $\left(83-76^{\circ} \mathrm{C}\right)$ when mixed with 3,5 and $10 \%$ gelatin as compared to WPI alone $\left(87^{\circ} \mathrm{C}\right)$ was due to the earlier setting of the WPI network (Figure 4a, Table 4). The gelation temperature of gelatin was verified from gelatin samples only (Figure 4b) that form a heat reversible gel while the WPI formed an irreversible gel which increased in strength upon heating and cooling. Since the gel formation of individual components can be identified in the mixed gel system by comparison with gel formation studies in the pure systems, the interpretation of the results (Figure 5) is that each component formed its own network resulting in a phase separated mixed gel (Walkenstrom \& Hermansson, 1996). Figure 5 shows that the final G' values for the mixed gel were higher than those of the individual gelatin and whey proteins in isolation, thus indicating synergistic interaction (Table 4).

Temperature sweeps were used to study the gelation behaviour of the 3,5 and $10 \%$ $(\mathrm{w} / \mathrm{w})$ chicken gelatin samples with the addition of $10 \%(\mathrm{w} / \mathrm{w})$ WPI solution to each concentration. The gelling temperatures of the resultant 3:10, 5: 10 and 10:10 (gelatin: WPI) mixtures were $83.65,82.32$ and $76.70{ }^{\circ} \mathrm{C}$ respectively and were significantly different $(\mathrm{p}<0.05)$ (Table 4). The $\mathrm{G}^{\prime}$ value obtained for $10 \% \mathrm{w} / \mathrm{w}$ gelatin on its own was high at $45,233 \mathrm{~Pa}$. The addition of small amounts of gelatin (3\% or 5\%) to $10 \%$ WPI resulted in higher than expected $G^{\prime}$ values i.e. 1860 and 23,914 in the mixed gels compared with $3 \%$ gelatin $(907 \mathrm{~Pa})$ and $5 \%$ gelatin $(8192 \mathrm{~Pa})$ on its own.

However, very high concentrations of gelatin in a mixed gel $(10 \%$ gelatin +10 $\%$ WPI) decreased the G' values from $45233 \mathrm{~Pa}$ for $10 \%$ gelatin on its own to 20145 $\mathrm{Pa}$ of the mixture i.e a weaker gel was formed (Table 4). This suggests that the presence of 
WPI in the mixture disturbed the continuity of gelatin network resulting in a weaker gelatin gel (Walkenstrom \& Hermansson, 1996); the gel formation of gelatin in the mixed gel is interpreted as WPI-continuous. This is in contrast to the large deformation results above, probably due to the different gelation techniques. Large deformation gels were formed at a single high temperature $90^{\circ} \mathrm{C}$ for $30 \mathrm{~min}$ and then cooled overnight and tested by compression. In contrast, the small deformation test is dynamic, measuring the $G^{\prime}$ (gel strength or elasticity) for a sample heated from a solution to a gel at $90{ }^{\circ} \mathrm{C}$ and then cooled to $20{ }^{\circ} \mathrm{C}$ immediately. It is likely that a longer period of heating time is required at the optimum temperature for the molecules to interact and form networks which strengthen on cooling especially for the higher concentrations of whey protein.

The highest interaction between gelatin and WPI was seen at $5 \%$ gelatin and $10 \%$ WPI. The G' values were significantly different $(\mathrm{p}<0.05)$ between the gelatin: WPI 3\%:10\% mixture and 5\%:10\% mixture or 10\%:10\% mixture; however, there was no significant difference $(\mathrm{p}>0.05)$ between the 5\%:10\% and 10\%:10\% mixtures. $\mathrm{G}^{\prime}$ value increases were possibly due to non-covalent interactions between gelatin and whey molecules. In addition, Clark et al., (1983) suggested that the increase in G' for BSA and agar mixtures was due to the fact that the hydrodynamic volume occupied by one polymer resulted in increasing the concentration of the second polymer in the remaining solution. However, the Flory-Huggins solution theory model states that two polymers are compatible when the free energy of interaction is negative. Because of the small number of molecules in the polymer mixture, the entropy of mixing will also be minimal and can be counteracted by a small positive energy of interaction and result in limited miscibility (Flory, 1953). As the mixing of proteins leads to endothermic reactions, molecules which are chemically different or have different molecular sizes may not be compatible. Similar results were reported for a mixture of whey protein and gelatin (Walkenstrom \& Hermansson, 1994) and egg albumen and fish gelatin (Badii \& Howell, 2006).

\subsubsection{Melting studies}

The melting temperatures of $10 \%(\mathrm{w} / \mathrm{w})$ gelatin alone was $36.02{ }^{\circ} \mathrm{C}$ and those of gelatin-whey proteins mixed in the ratios $3: 10,5: 10$ and 10:10 were $30.65,32.37$ and $32.14{ }^{\circ} \mathrm{C}$ respectively and not significantly different $(\mathrm{p}>0.05)$ (Table 4). The melting temperatures of gelatin at different concentrations decreased in the presence of $10 \%(\mathrm{w} / \mathrm{w})$ whey proteins. Furthermore, the melting mechanisms of gelatin and WPI were different and 
could be identified in the mixed gel by comparing the melting behaviour of the individual protein. Results showed that the mixed gels containing $10 \%$ (w/w) WPI did not melt once formed, suggesting a continuous network of WPI in the mixed gel. This is in agreement with Cooney et al., (1993), Comfort \& Howell, (2002) and Ngarize et al., (2005), who found that the gel setting for whey proteins began during heating and the gel stiffness increased during the cooling period. In contrast, gelatin gels set on cooling and melt on heating. An increase in the gelatin concentration in the mixture contributed to a higher degree of association of gelatin, which contributed to the gel strength of the mixed gels resulting in the higher melting temperature. Although the $G^{\prime}$ values for both individual W P I and mixed gels increased after heating, these $G^{\prime}$ values were less than those obtained. For example, $\mathrm{G}^{\prime}$ for $10 \%(\mathrm{w} / \mathrm{w})$ gelatin alone was higher than that of the mixture of $10 \%$ gelatin $+10 \%$ WPI which surprisingly resulted in a weak gel. Therefore, whey proteins interfered with the formation of gelatin networks.

\subsubsection{Frequency sweeps}

The strength of the gel network can be obtained by studying the frequency dependence of G' (Clark \& Ross-Murphy, 1987). For example, an entangled network shows frequency dependence, while a covalent, strong gel shows frequency independence. The frequency sweep curve gives a good rheological description of how the product will behave during storage and application. Figure $6 \mathrm{a}$ and $\mathrm{b}$ show $\mathrm{G}^{\prime}$ and $\mathrm{G}^{\prime \prime}$ as a function of frequency over $0-25 \mathrm{rad} / \mathrm{s}$ for $10 \%(\mathrm{w} / \mathrm{w})$ gelatin and whey protein solutions respectively. The G' and G" values for gelatin solutions were independent of the frequency and far higher than that of whey solution which indicated that gelatin formed a strong gel compared to whey proteins. This is evident as $\tan \delta\left(\mathrm{G}^{\prime \prime} / \mathrm{G}^{\prime}\right)$ of gelatin was lower than 0.1 , indicative of a good gel network or more solid-like nature of the material (Hudson et al., 2000). Gilsenam \& Ross-Murphy (2000) showed a slight dependence of G' on frequency in their study of cod skin gelatin gels, which became less obvious as the gelatin concentration increased. For mammalian gelatin gels too, Te Nijenhuis (1981) showed the dependence of the storage modulus on frequency and suggested that this dependence varied with maturation time. In contrast, WPI showed a much lower $\mathrm{G}^{\prime}$ and $\mathrm{G}^{\prime \prime}(\mathrm{P}<0.05)$ as a function of frequency compared to gelatin solution and was slightly frequency dependent. Tan $\delta$ of WPI was higher than $G^{\prime}$ and $G^{\prime \prime}$ at every frequency and also the $G^{\prime \prime}$ was higher than that of $G^{\prime}$ at the beginning of the frequency sweep. The difference in behaviour, with frequency, between gelatin and WPI suggests that $10 \%(\mathrm{w} / \mathrm{w})$ WPI produced weak gels with an 
504 inhomogeneous and aggregated structure compared with the gelatin gel. This suggestion 505 was confirmed by microscopy of the gels (Figure 8,9).

506

507

Similarly, Figure 6c compares the frequency sweeps of mixtures of chicken gelatin 508 and WPI (gelatin: WPI 3:10, 5:10 and 10:10). The storage modulus $\left(\mathrm{G}^{\prime}\right)$, of the mixture 509 increased with the addition of gelatin $(3,5$ and $10 \%(\mathrm{w} / \mathrm{w})$ to $10 \%(\mathrm{w} / \mathrm{w}) \mathrm{WPI}$, and was 510 frequency independent. This suggests an increase in the strength and stability of the native 511 protein structure, resulting in resistance to unfolding probably due to hydrophobic 512 interactions, (Mangino, 1984). Figure 7 confirmed that 3:10 (gelatin: WPI) mixed gel 513 was frequency independent. $G^{\prime}$ was higher than $G^{\prime \prime}$ and $\tan \delta$ values were low at all 514 frequencies indicating a strong, stable gel network. Therefore, the addition of gelatin to whey 515 protein solutions improve whey protein gel structures and could result in innovative texture 516 and applications. 


\subsection{Phase contrast microscopy}

The microstructure of $10 \%(\mathrm{w} / \mathrm{w})$ gelatin and whey proteins in distilled water by phase contrast microscopy is shown in Figure 8. Gelatin exhibited a fine uniform and homogeneous network structure with very small particles whereas the whey protein structure was more irregular with $\mathrm{larger}$ aggregates. The finer structure of gelatin gels concurs with the higher gel strength observed by both the small and large deformation tests in this study, compared to the lower gel strength values shown by whey proteins, which possessed coarser gel structure that broke easily when force was applied. The $T_{m}$ of $10 \%(\mathrm{w} / \mathrm{w})$ gelatin alone was $31.16^{\circ} \mathrm{C}$; however, the addition of $10 \%$ (w/w) WPI decreased the $\mathrm{Tm}$ of the mixture to $27.87^{\circ} \mathrm{C}$ as presented in Table 1 . In gelatin:WPI mixtures the increased interaction particularly for 5\% gelatin and $10 \%$ whey mixture may have been influenced by the lowering of the $\mathrm{T}_{m}$ allowing the unfolded WPI molecules to interact with the gelatin molecules by non-covalent bonds.

Figure $9 \mathrm{a}, \mathrm{b}$ and $\mathrm{c}$ show the differences in the structure of the mixed gels comprising gelatin at 3,5 and $10 \%(\mathrm{w} / \mathrm{w})$ a $10 \%$ WPI $(\mathrm{w} / \mathrm{w})$ in distilled water respectively. In the mixed gels, the polymers formed a bi-continuous network, indicating the incompatibility between the two protein networks. Phase contrast micrographs of a mixture of gelatin: WPI 3:10 ratio showed a uniform structure with small aggregates compared to mixtures containing higher concentrations of gelatin (5:10 and 10:10, gelatin: WPI mixtures). Furthermore, gelation studies showed that the gel formation of WPI was independent of the presence of gelatin, suggesting that the network development for WPI in the mixed gels is similar to that of a pure WPI gel. Thus, as the WPI network is formed first, it may act like a mould allowing the gelatin to form a network in the pores, as suggested by Walkenstrom \& Hermansson, (1996). In contrast, the mixture containing gelatin/WPI 5:10 ratio showed a more dense, irregular and uneven network indicating a bi-continuous system. The denser structure of the gelatin/WPI 5:10 mixture is indicative of a stronger gel than the network structure for the 3:10 mixture. This trend was also seen in the gelatin/WPI 10:10 ratio which resulted in the formation of an ordered structure with finer strands, compared to the gelatin/WPI 5:10 ratio. The higher gelatin concentration in the mixture resulted in the formation of predominantly gelatin continuous gel, with a lower WPI aggregated fraction leading to a less porous and more compact network structure that is positively correlated to the higher gel strength compared with gels containing lower gelatin concentrations ( 3 and $5 \%$ ) as the dense microstructure has more 
strands to absorb stress. The discontinuous whey protein network structure was composed of aggregates of various size and shapes, distributed in a continuous gelatin phase to form a phase separated network (Walkenström \& Hermansson, (1997); Camp \& Huyghebaert, (1995). Similarly, Badii \& Howell (2006) found that mixing $3 \%$ horse mackerel fish gelatin with $10 \%$ egg albumen proteins resulted in a reduction of interactions between egg albumen proteins with each other that would otherwise lead to aggregation. In conclusion, there was phase separation observed in chicken skin gelatin and whey protein mixed gels and higher concentrations of gelatin promoted a strong and uniform gel network.

\section{CONCLUSIONS}

The addition of small amounts gelatin 3 or $5 \%$ to $10 \%$ WPI resulted in G' values that were greater than expected indicating synergistic interactions between the two proteins. However, very high concentrations $10 \%$ gelatin with $10 \%$ WPI gave lower G' values than the $5 \%$ gelatin and $10 \%$ WPI mixture or $10 \%$ gelatin on its own, by small deformation rheology (temperature sweep). All combinations of gelatin and WPI proteins gave higher than expected gel strength values by large deformation rheological test (heat gelation followed by cooling and compression) thus indicating synergistic interaction and enhancement of the gelling properties of both gelatin and whey proteins. The addition of $10 \%$ whey protein lowered the denaturation temperature $\left(T_{m}\right)$ and increased $\Delta H$ of gelatin for different concentrations of gelatin (3, 5 and 10\%) as determined by DSC. Phase contrast microscopy showed phase separation of the two proteins in mixed gels and confirmed that the WPI network formed similar aggregates in the absence and presence of gelatin; In contrast, low concentrations of the gelatin network filled the spaces created by the whey protein gel which heat sets prior to the gelation of gelatin on cooling. A high concentration $(10 \%)$ of gelatin formed a gelatin continuous network. This study confirms that gelatin from a novel source, chicken skin that is a byproduct of filleting, can be used in combination with other food proteins like whey protein isolate to enhance gelation properties and texture in food and pharmaceutical applications.

\section{REFERENCES}

AOAC. (2006). Official methods of analysis of AOAC international (18 $\mathrm{Ed})$. Virginia, USA: Association of Official and Analytical Chemists International. 
Badii, F., \& Howell, N. K. (2006). Fish gelatin: Structure, gelling properties and interaction with egg albumen proteins. Food Hydrocolloids, 20, 630-640.

Bottomley, R. C., Evans, M. T. A., \& Parkinson, C. J. (1990). Whey proteins. In P. Harris (Ed.), Food gels (pp. 435-466). London: Elsevier.

Brink, J., Langton, M., Stading, M. \& Hermansson, A. (2007). Simultaneous analysis of the structural and mechanical changes during large deformation of whey protein isolate/ gelatin gels at the macro and micro levels. Food Hydrocolloids, 21, 409-419.

Burrington, K. J. (1998). More than just milk. Food Product Design, 7(10), 91-111.

Butler, M. F., \& Heppenstall-Butler, M. (2003). Phase separation in gelatin/dextran and gelatin/maltodextrin mixtures. Food Hydrocolloids, 17, 815-830.

Camp, J. V. \& Huyghebaert, A. (1995). A comparative rheological study of heat and high pressure induced whey protein gels. Food Chemistry, 54, (4), 357-364.

Cheow, C. S., Norizah, M. S., Kyaw, Z. Y. \& Howell, N. K. (2007). Preparation and characterisation of gelatins from the skins of sin croaker (Johnius dussumieri) and shortfin scad (Decapterus macrosoma). Food Chemistry, 101, 386-391.

Clark, A. H., Richardson, R. K., Robinson, G., Ross-Murphy, S. \& Weaver, A. C. (1982). Structural and mechanical properties of agar/BSA co-gels. Progress in Food and Nutrition Science, 6, 149-160.

Clark, A. H., Richardson, R. K., Ross-Murphy, S. B. \& Stubbs, J. M. (1983). Structural and Mechanical Properties of Agar/Gelatin Co-gels. Small-Deformation Studies. Macromolecules, 16, 1367-1374.

Clark, A. H. \& Ross-Murphy, S. B. (1987). Structural and mechanical properties of biopolymer gels. Advances in Polymer Science, 83, 57-192

Cooney, M. J., Rosenberg, M. \& Shoemaker, D. F. (1993). Rheological properties of whey protein concentrate gels. J. Texture Stud, 24, 325-334.

Chronakis, I. S. \& Kasapis, S. (1993). Structural properties of single and mixed milk/soya protein systems. Food Hydrocolloids, 7, (6) 459-478.

Comfort, S. \& Howell, N. K. (2002). Gelation properties of soya and whey protein isolate mixtures. Food Hydrocolloids, 16, 661-672.

Comfort, S. \& Howell, N. K. (2003). Gelation properties of soluble wheat proteins and meat protein mixtures. Food Hydrocolloids, 17, 149-159.

De Wit, J. N. (1998). Nutritional and functional characteristics of whey protein in food products. Journal of Dairy Science, 81, 597-608. 
Doume' che, B., Picard, J. \& Larreta-Garde, V. (2007). Enzymatic tailoring of alginate

gels and gelatin-alginate IPN. Biomacromolecules, 8(11), 3613-3618.

Fitzsimons, S. M., Mulvihill, D. M., \& Morris, E. R. (2008). Segregative interactions between gelatin and polymerised whey protein. Food Hydrocolloids, 22, 485-491.

Gilsenam, P. M., \& Ross-Murphy, S. B. (2000). Viscoelasticity of thermoreversible gelatin gels from mammalian and piscine collagen. J Rheol, 44, 871-82.

Gilsenam, P. M., Richardson, R. K., \& Morris, E. R. (2003). Associative and segregative interactions between gelatin and low-methoxy pectin: part 3. Quantitative analysis of cogel moduli. Food Hydrocolloids, 17(6), 751-761.

Howell, N. K., \& Lawrie, R. A. (1984). Functional aspects of blood plasma proteins. 4. Elucidation of the mechanism of gelation of plasma and egg albumen proteins. Journal of Food Technology, 20, 489-504.

Howell, N. K. (1994). Elucidation of protein-protein interactions in gels and foams. In Gums and stabilisers for the food industry 7. G.O Philips, P.A. William and D.J. Wedlock (eds). IRL Press, Oxford University Press, pp. 77-89

Hudson, H. M., Daubert, C. R. \& Foegeding, E. A. (2000). Rheological and physical properties of derivitized whey protein isolate powders. Journal of Agricultural and Food Chemistry, 48, 3112-3119.

Huffman, L. (1996). Processing whey protein for use as a food ingredient. Food Technology, 50 (2), 49-52.

Joly-Duhamel, C., Hellio, D. \& Djabourov, M. (2002). All gelatin networks: 1. Biodiversity and physical chemistry. Langmuir, 18(19), 7208-7217.

Jiang, Y., Li, Y., Chai, Z. \& Leng, X. (2010). Study of the physical properties of whey protein isolate and gelatin composite films. Journal of Agricultural and Food Chemistry, 58(8), 5100-5108.

Kasapis, S., Morris, E. R., Norton, I. T. \& Clark, A. H. (1993). Phase equilibria and gelation in gelatin/maltodextrin systems-Part IV: Composition-dependence of mixed-gel moduli. Carbohydrate Polymers, 21, 269-276.

Loren, N. \& Hermansson, A. M. (2000). Phase separation and gel formation in kinetically trapped gelatin/maltodextrin gels. International Journal of Biological Macromolecules, 27(4), 249-262.

Loren, N., Hermansson, A. M., Williams, M. A. K., Lundin, L., Foster, T. J. \& Hubbard, C. D. (2001). Phase separation induced by conformational ordering of gelatin in gelatin/maltodextrin mixtures. Macromolecules, 34 (2), 289-297.

Mangino, M.E., (1984). Physicochemical aspects of whey protein functionality. Journal 
McLachlan, A. D., \& Karn, J. (1982). Periodic charge distributions in the myosin rod amino acid sequence match cross-bridge spacing in muscle. Nature, 299, 226-231.

Michon, C., Cuvelier, G., Launay, B. \& Parker, A. (1997). Interactions in mixture of gelatin and i-carrageenan. In E. Dickinson and B. Bergenstahl, Food colloids. Proteins, lipids and polysaccharides (pp. 316-325). Cambridge: The Royal Society of Chemistry.

Mulvihill, D. M. \& Ennis, M. P. (2003). Functional milk proteins: Production and utilisation. In P. F. Fox, and P. L. H. McSweeney (Eds.), Advanced dairy chemistry. Part B, Vol. 1 (pp.1175-1228). New York: Kluwer Academic.

Ngarize, S., Adams, A. \& Howell, N. K. (2005). A comparative study of heat and high pressure induced gels of whey and egg albumen proteins and their binary mixtures. Food Hydrocolloids. 19, 984-996.

Norton, I. T. \& Frith, W. J. (2001). Microstructure design in mixed biopolymer composites. Food Hydrocolloids, 15(4-6), 543-553.

Papageorgiou, M., Kasapis, S. \& Richardson, R. K. (1994). Steric exclusion phenomena in gellan/gelatin systems I. Physical properties of single and binary gels. Food Hydrocolloids, 8,(2), 97- 112.

Plucknett, K. P., Normand, V., Pomfret, S. J. \& Ferdinando, D. (2000). 'Ductile' mixed biopolymer gel composites. Polymer, 41(6), 2319-2323.

Sakamoto, H., Kumazawa, Y. \& Motoki, M. (1994). Strength of protein gels prepared with microbial transglutaminase as related to reaction conditions. J. Food Sci. 59, 866-871.

Sarbon, N., Badii, F. \& Howell, N. K. (2013). Preparation and characterisation of chicken skin gelatin as an alternative to mammalian gelatin. Food Hydrocolloids, 30, 143151.

Stainsby, G. (1977). In Ward, A.G. \& Courts, A. (eds), Food Science and Technology. Academic Press, London, pp. 179.

Stading, M., Langton, M. \& Hermansson, A-M. (1993). Microstructure and rheological behaviour of particulate $\beta$-lactoglobulin gels. Food Hydrocolloids, 7, (3),195-212.

Stainsby, G. (1977). The physical chemistry of gelatin in solution. In A. G. Ward, and A. Courts (Eds.), The science and technology of gelatine (pp. 109-135). London: Academic Press.

Te Nijenhuis, K. (1981). Investigation into the ageing process in gels of gelatin/water systems by the measurement of their dynamic moduli: part I-phenomenology. Colloid and Polymer Sci, 259, 522-35.

Tolstoguzov, V. B. (1992). In G. Philips, P. Williams, and D. Wedlock (Eds.), Interactions of gelatin with polysaccharides. Gums and stabilisers in the food industry, Vol. 6 (pp. 241- 
Tolstoguzov, V. B. (1995). Some physico-chemical aspects of protein processing in

Walkenström, P. \& Hermansson, A. M. (1994). Mixed gels of fine-stranded and particulate networks of gelatin and whey proteins. Food Hydrocolloids, 8, 589-607.

Walkenström, P. \& Hermansson, A. M. (1996). Fine-stranded mixed gels of whey proteins and gelatin. Food Hydrocolloids, 10, 51-62.

Walkenström, P. \& Hermansson, A. M (1997). High pressure treated mixed gels of gelatin and whey proteins. Food Hydrocolloids, 11, 195-208.

Zúñiga, R.N., Kulozik, U., Aguilera, J. M. (2011). Ultrasonic generation of aerated gelatin gels stabilized by whey protein $\beta$-lactoglobulin. Food Hydrocolloids, 25, 958-967. 
Table 1. Denaturation temperature $\left(T_{m},{ }^{\circ} \mathrm{C}\right)$ values of different concentration and ratios of gelatin and gelatin/whey mixtures obtained in $1^{\text {st }}$ and $2^{\text {nd }}$ cycle of heating

\begin{tabular}{cccccc}
\hline $\begin{array}{c}\text { Gelatin } \\
\text { conc. }\end{array}$ & $\begin{array}{c}\boldsymbol{T}_{\boldsymbol{m}}\left({ }^{\circ} \mathbf{C}\right) \\
\text { Cycle 1 }\end{array}$ & \multicolumn{2}{c}{$\begin{array}{c}\boldsymbol{T}_{\boldsymbol{m}}\left({ }^{\circ} \mathbf{C}\right) \\
\text { Cycle 2 }\end{array}$} & WPI \\
\hline & Without whey & $\mathbf{+ 1 0} \%$ whey & Without whey & $\begin{array}{c}+\mathbf{1 0} \% \\
\text { whey }\end{array}$ & $\mathbf{1 0 \%}$ \\
& & & & \\
$\mathbf{3} \%$ & $30.99 \pm 0.14 \mathrm{aA}$ & $28.79 \pm 0.96 \mathrm{aB}$ & $27.42 \pm 0.44 \mathrm{cC}$ & $26.91 \pm 0.03 \mathrm{cD}$ & $74.93 \pm 0.05$ \\
$\mathbf{5 \%}$ & $30.73 \pm 0.18 \mathrm{aA}$ & $28.58 \pm 0.24 \mathrm{aB}$ & $28.15 \pm 0.02 \mathrm{dC}$ & $26.30 \pm 0.21 \mathrm{cD}$ & $75.94 \pm 0.88$ \\
$\mathbf{1 0 \%}$ & $31.16 \pm 0.35 \mathrm{aA}$ & $27.87 \pm 0.38 \mathrm{aB}$ & $28.18 \pm 0.10 \mathrm{dC}$ & $25.86 \pm 0.01 \mathrm{dD}$ & $77.04 \pm 0.15$ \\
- & & & & & $67.65 \pm 0.01$ \\
\hline
\end{tabular}

Each value is a mean of triplicate determinations and is reported with its standard deviation. a-d Means within a column are significantly different $(\mathrm{p}<0.05)$. 
Table 2. Enthalpy change $(\Delta H, \mathrm{~J} / \mathrm{g})$ values of different concentrations and ratios of gelatin and gelatin/whey mixtures obtained in $1^{\text {st }}$ and $2^{\text {nd }}$ cycle of heating

\begin{tabular}{cccccc}
\hline Gelatin conc. & \multicolumn{2}{c}{$\begin{array}{c}\text { Enthalphy }(\boldsymbol{\Delta H}) \\
\text { Cycle 1 }\end{array}$} & \multicolumn{2}{c}{$\begin{array}{c}\text { Enthalphy }(\boldsymbol{\Delta H}) \\
\text { Cycle 2 }\end{array}$} & WPI \\
\hline & $\begin{array}{c}\text { Without } \\
\text { whey }\end{array}$ & $\mathbf{+ 1 0} \%$ whey & $\begin{array}{c}\text { Without } \\
\text { whey }\end{array}$ & $\mathbf{+ 1 0 \%}$ whey & $\mathbf{1 0 \%}$ \\
& $0.36 \pm 0.02 \mathrm{aA}$ & $0.62 \pm 0.04 \mathrm{aB}$ & $0.48 \pm 0.02 \mathrm{cC}$ & $0.54 \pm 0.00 \mathrm{cD}$ & $0.37 \pm 0.01$ \\
$\mathbf{3} \%$ & $0.50 \pm 0.01 \mathrm{bA}$ & $1.34 \pm 0.06 \mathrm{bB}$ & $1.03 \pm 0.13 \mathrm{dC}$ & $1.27 \pm 0.05 \mathrm{dD}$ & $0.40 \pm 0.01$ \\
$\mathbf{5 \%}$ & $0.88 \pm 0.05 \mathrm{cA}$ & $2.20 \pm 0.18 \mathrm{cB}$ & $2.06 \pm 0.03 \mathrm{eC}$ & $2.04 \pm 0.08 \mathrm{eC}$ & $0.46 \pm 0.02$ \\
$\mathbf{1 0 \%}$ & & & & & $0.75 \pm 0.06$ \\
\hline
\end{tabular}

Each value is a mean of triplicate determinations and is reported with its standard deviation. a-f Means within a column with different letters are significantly different $(\mathrm{p}<0.05)$. A-D Means within a row with different letters are significantly different $(\mathrm{p}<0.05)$. 
Table 3. Comparison of large deformation (gel strength values) for whey and gelatin mixed in the ratio $3: 10,5: 10$ and 10:10.

\begin{tabular}{ccc}
\hline $\begin{array}{c}\text { Concentrations } \\
\text { (Gelatin:Whey) }\end{array}$ & Force (g) & Area (gs) \\
\hline $\mathbf{1 0 : 0}$ & $241 \pm 6$ & $4890 \pm 61$ \\
$\mathbf{3 : 1 0}$ & $459 \pm 7$ & $8,888 \pm 14$ \\
$\mathbf{5 : 1 0}$ & $578 \pm 10$ & $12,012 \pm 212$ \\
$\mathbf{1 0 : 1 0}$ & $897 \pm 8$ & $17,940 \pm 178$ \\
\hline
\end{tabular}


Table 4. Comparison of gelling and melting temperatures of gelatin and whey protein

\begin{tabular}{cccc}
\hline $\begin{array}{c}\text { Conc. } \\
\text { (Gelatin:WPI) }\end{array}$ & $\begin{array}{c}\text { Melting } \\
\text { Temperature } \\
\left({ }^{\circ} \mathbf{C}\right)\end{array}$ & $\begin{array}{c}\text { Gelling } \\
\text { Temperature } \\
\left({ }^{\circ} \mathbf{C}\right)\end{array}$ & $\begin{array}{c}\text { Maximum value } \\
\text { of G' }(\mathbf{P a}) \\
\text { after cooling to 10 }\end{array}$ \\
\hline $\mathbf{3 : 0}$ & $32.67 \pm 0.28$ & $21.02 \pm 0.07$ & 907 \\
$\mathbf{5 : 0}$ & $32.82 \pm 0.92$ & $23.34 \pm 0.60$ & 8192 \\
$\mathbf{1 0 : 0}$ & $36.02 \pm 0.50$ & $27.19 \pm 0.45$ & 45233 \\
$\mathbf{3 : 1 0}$ & $30.65 \pm 0.31$ & $83.65 \pm 0.06$ & 1860 \\
$\mathbf{5 : 1 0}$ & $32.37 \pm 0.23$ & $82.32 \pm 0.74$ & 23914 \\
$\mathbf{1 0 : 1 0}$ & $32.14 \pm 0.70$ & $76.70 \pm 0.28$ & 20145 \\
$\mathbf{0 : 1 0}$ & - & $87.75 \pm 0.24$ & 120 \\
\hline
\end{tabular}




\section{List of figure headings}

Figure 1: DSC thermogram of (a) $10 \%(w / v)$ chicken skin gelatin and (b) $10 \%(w / v)$ whey protein showing the first (blue) and second (red) heating cycles

Figure 2: DSC thermogram showing the thermal properties of gelatin/whey protein mixed in the ratio 10:10 during the first (blue) and second (red) heating cycle

Figure 3: A comparison of the thermal properties of chicken skin gelatin and whey proteins mixed in the ratio gelatin:whey, $3: 10,5: 10$ and 10:10 in the $1^{\text {st }}$ heating cycle.

Figure 4: Small deformation temperature sweep from $20{ }^{\circ} \mathrm{C}$ to $90{ }^{\circ} \mathrm{C}$ and cooled back to $20{ }^{\circ} \mathrm{C}$ of a) $10 \%(\mathrm{w} / \mathrm{w})$ whey protein isolate (WPI), b) $3 \%(\mathrm{w} / \mathrm{w})$ gelatin and c) a mixture of chicken skin gelatin $(3 \%)$ and whey proteins $(10 \%) \mathrm{w} / \mathrm{w}$ in distilled water.

Figure 5: A comparisons of rheograms for $3 \%$ gelatin, $10 \%$ WPI and their mixture (w/w) in distilled water heated from $20^{\circ} \mathrm{C}$ to $90{ }^{\circ} \mathrm{C}$ and cooled back to $20^{\circ} \mathrm{C}$.

Figure 6: Small deformation frequency sweeps $(0-100 \mathrm{rad} / \mathrm{sec})$ of a) $10 \%(\mathrm{w} / \mathrm{w})$ chicken skin gelatin, b) $10 \%(w / w)$ whey protein isolate (WPI) and c) chicken skin gelatin and WPI proteins mixed in the ratio 3:10, 5:10 and 10:10 (gelatin:WPI) all in distilled water.

Figure 7: Frequency sweep $(0-100 \mathrm{rad} / \mathrm{sec})$ showing $\mathrm{G}^{\prime}, \mathrm{G}$ ', and tan delta values for chicken skin gelatin and whey protein isolate (WPI) mixed in the ratio 3:10 (gelatin:WPI).

Figure 8: Phase contrast micrographs showing the gel structures of a) $10 \%$ gelatin and b) $10 \%$ whey proteins $(\mathrm{w} / \mathrm{w})$ in distilled water. Magnification x100.

Figure 9: Phase contrast micrographs of chicken skin gelatin:whey protein isolate proteins mixed in the ratio a) 3:10, b) 5:10 and c) 10:10. Magnification x100. 


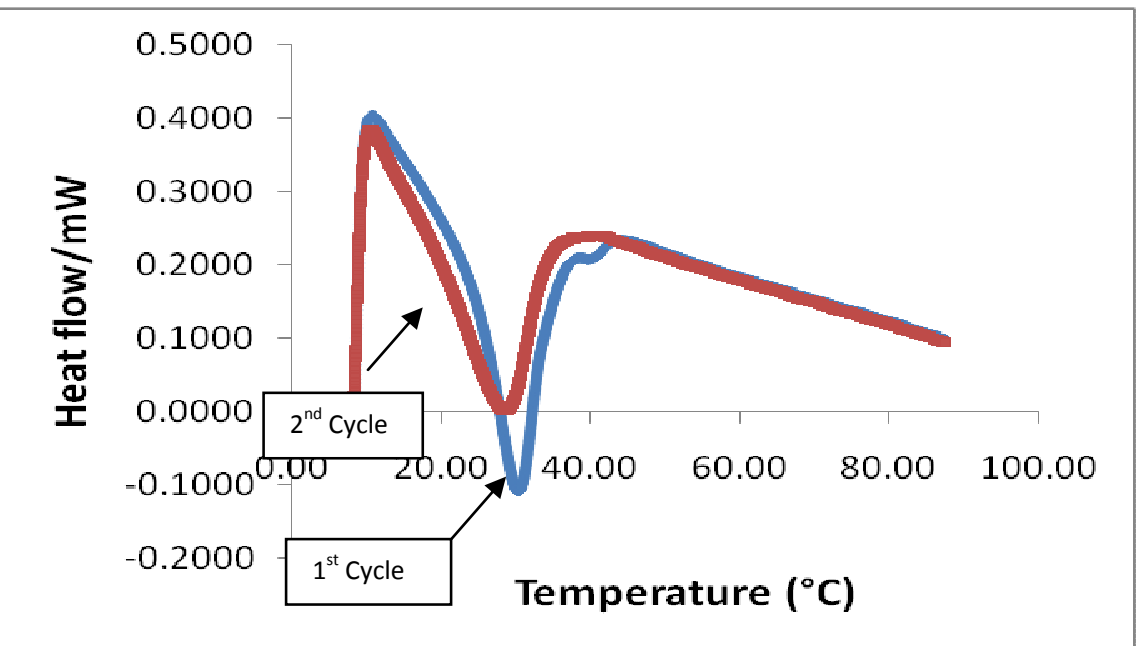

42

$43 \quad 1 b$

44

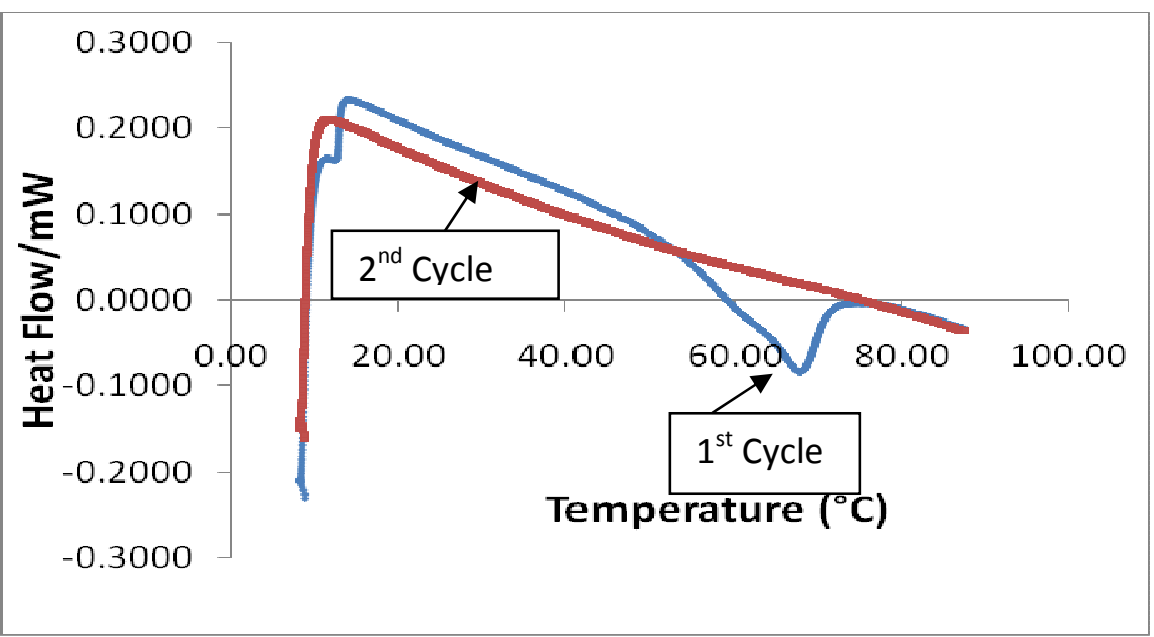

45 
$47 \quad$ Figure 2

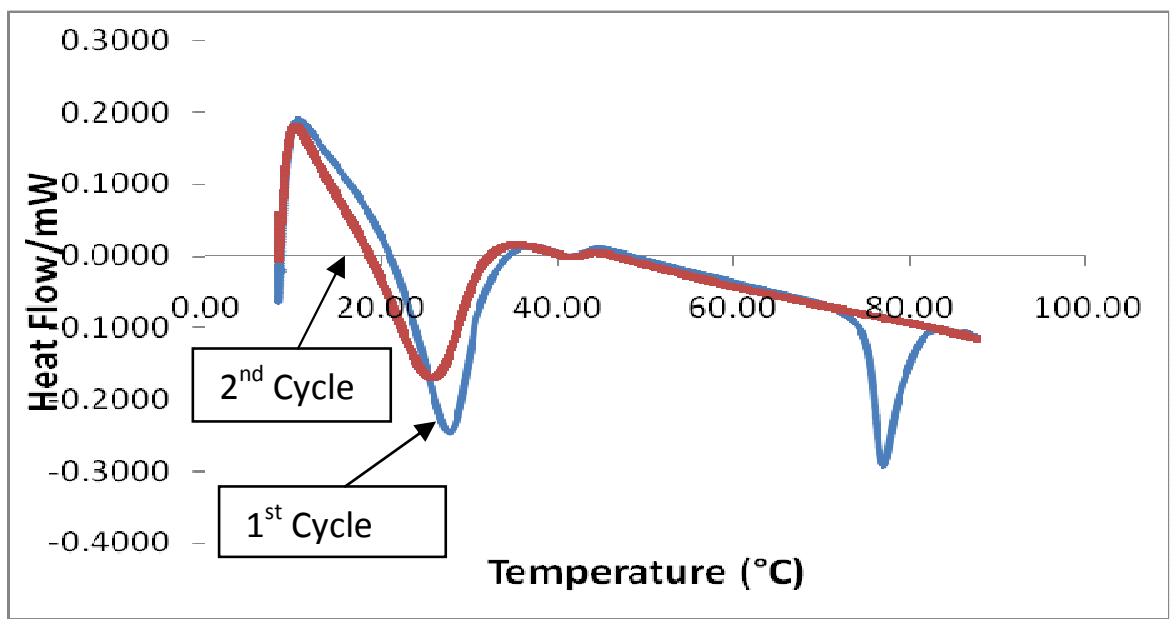

49 
Figure 3

51

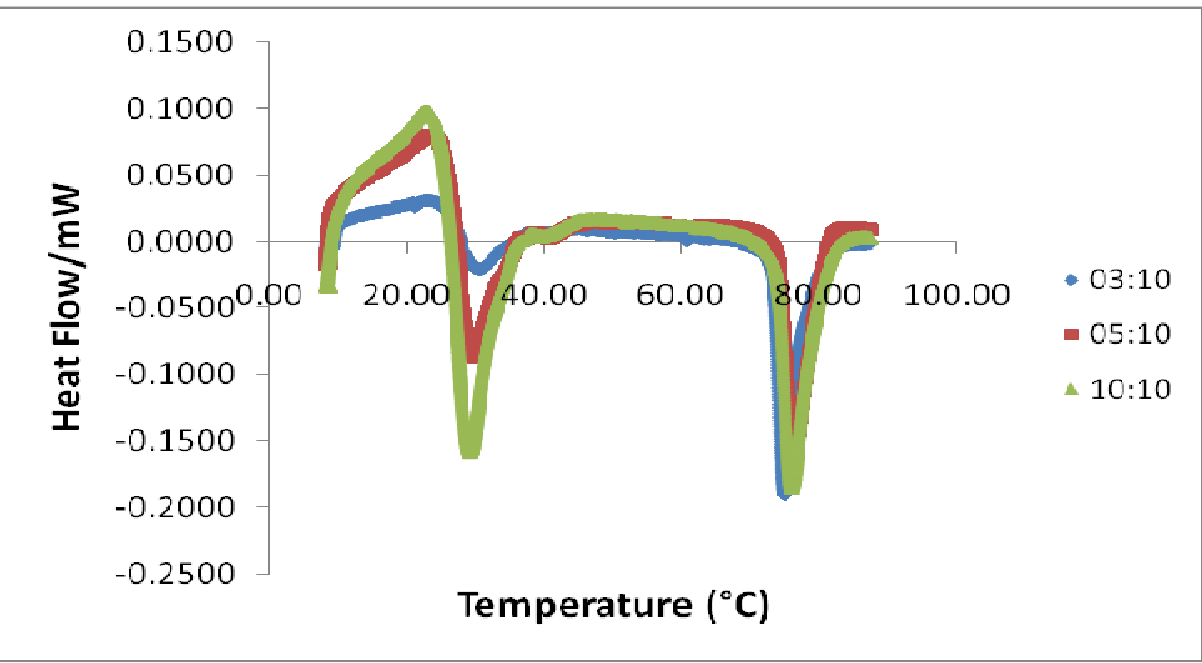

52

53 


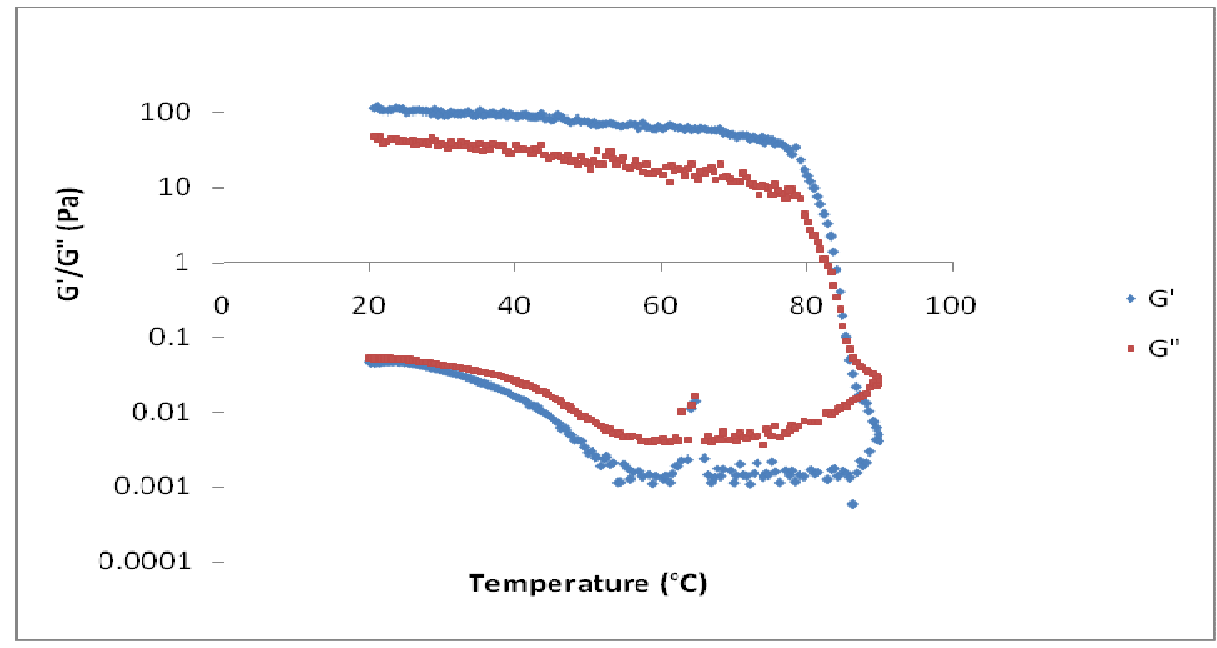

56

57 Figure 4b: Gelatin

58

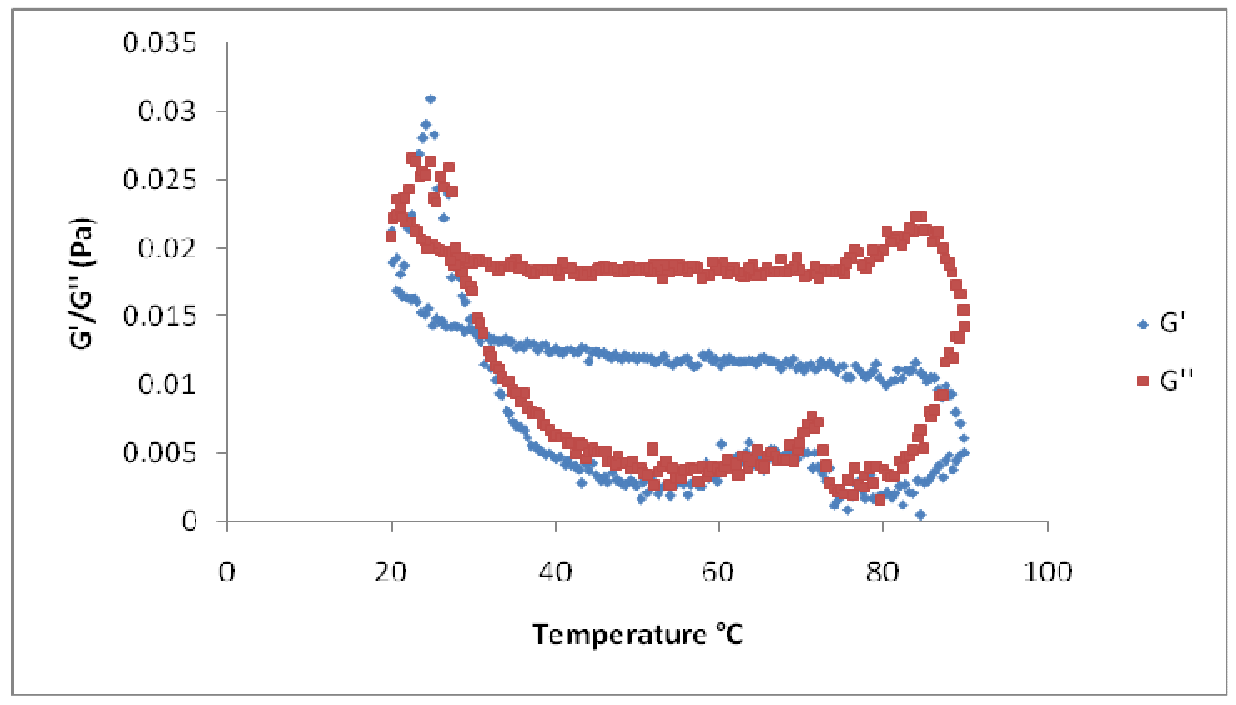

59

Figure 4c: Mixture

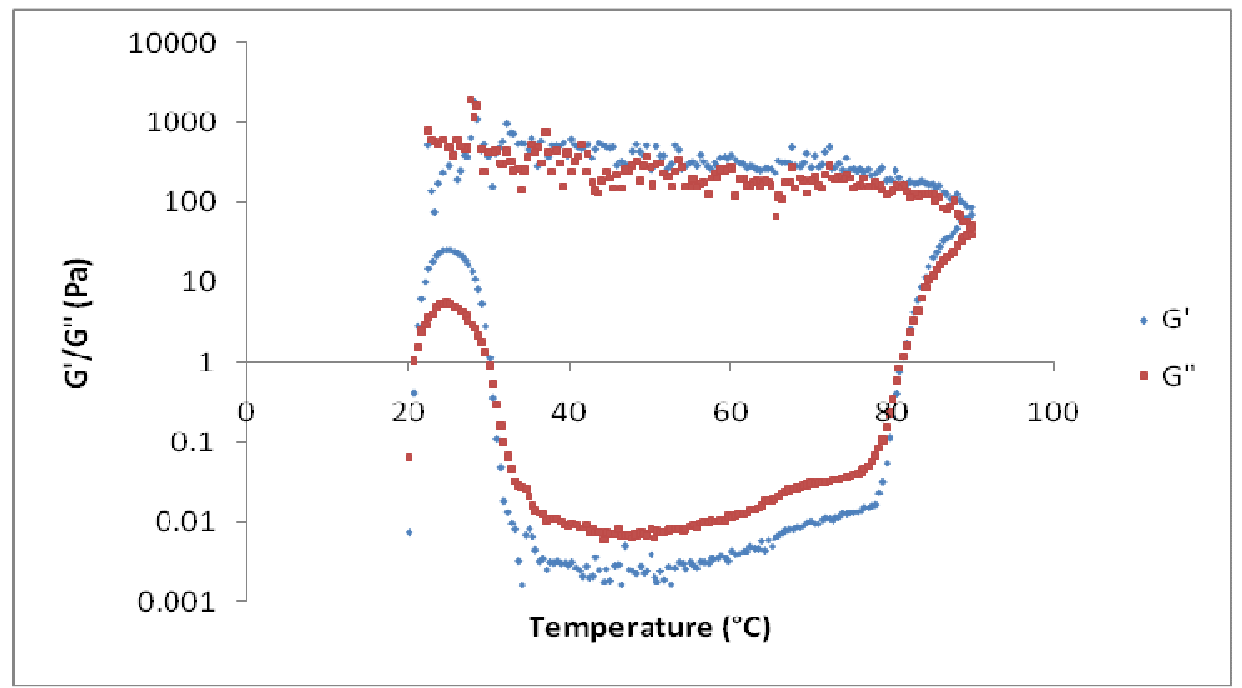


61

62 Figure 5

63

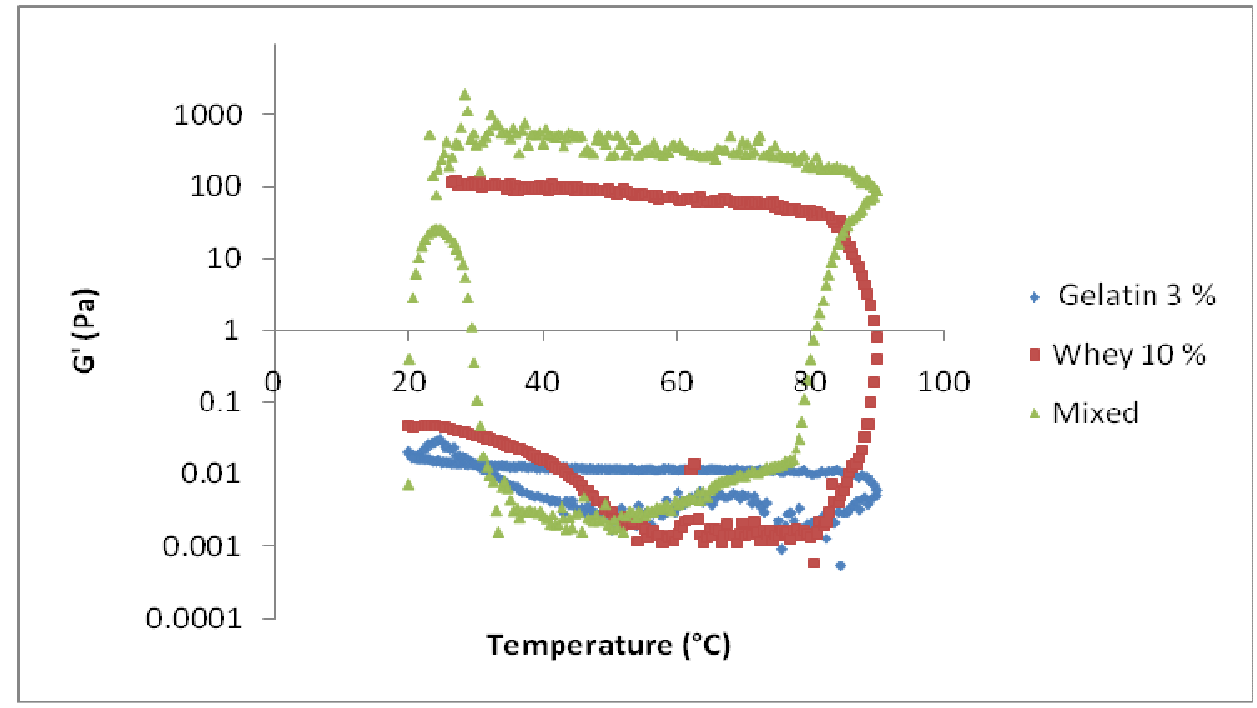

64 


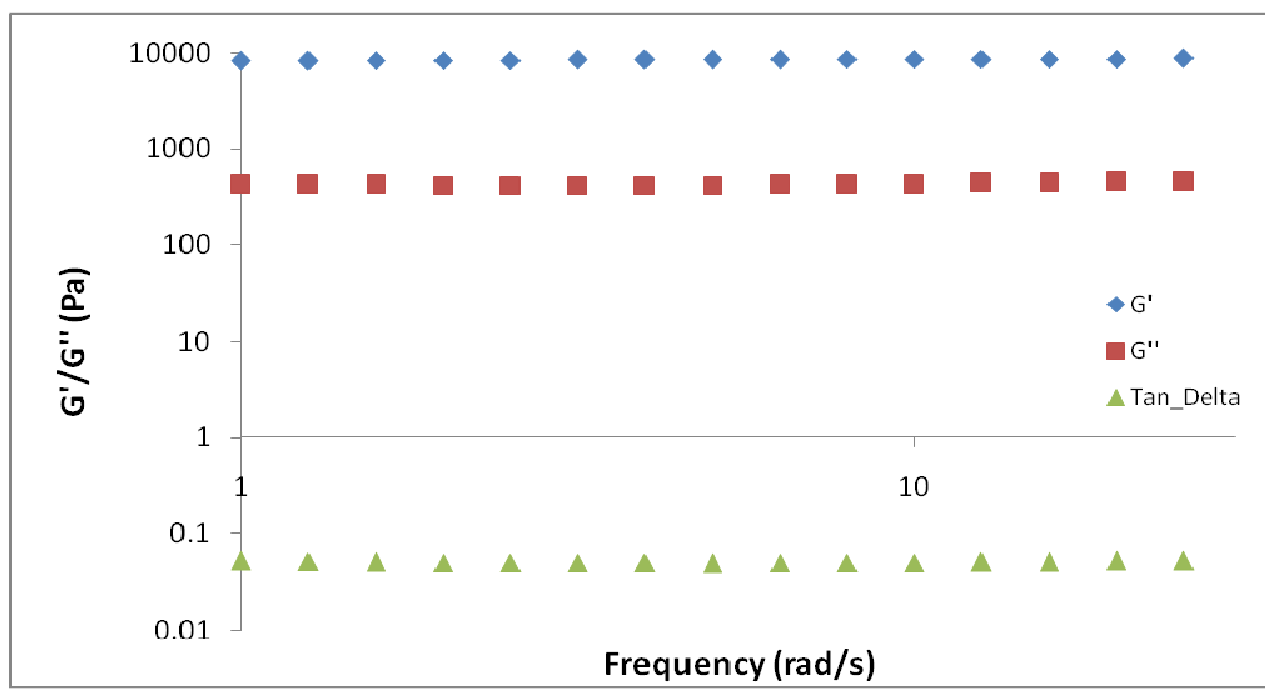

67 Figure 6b

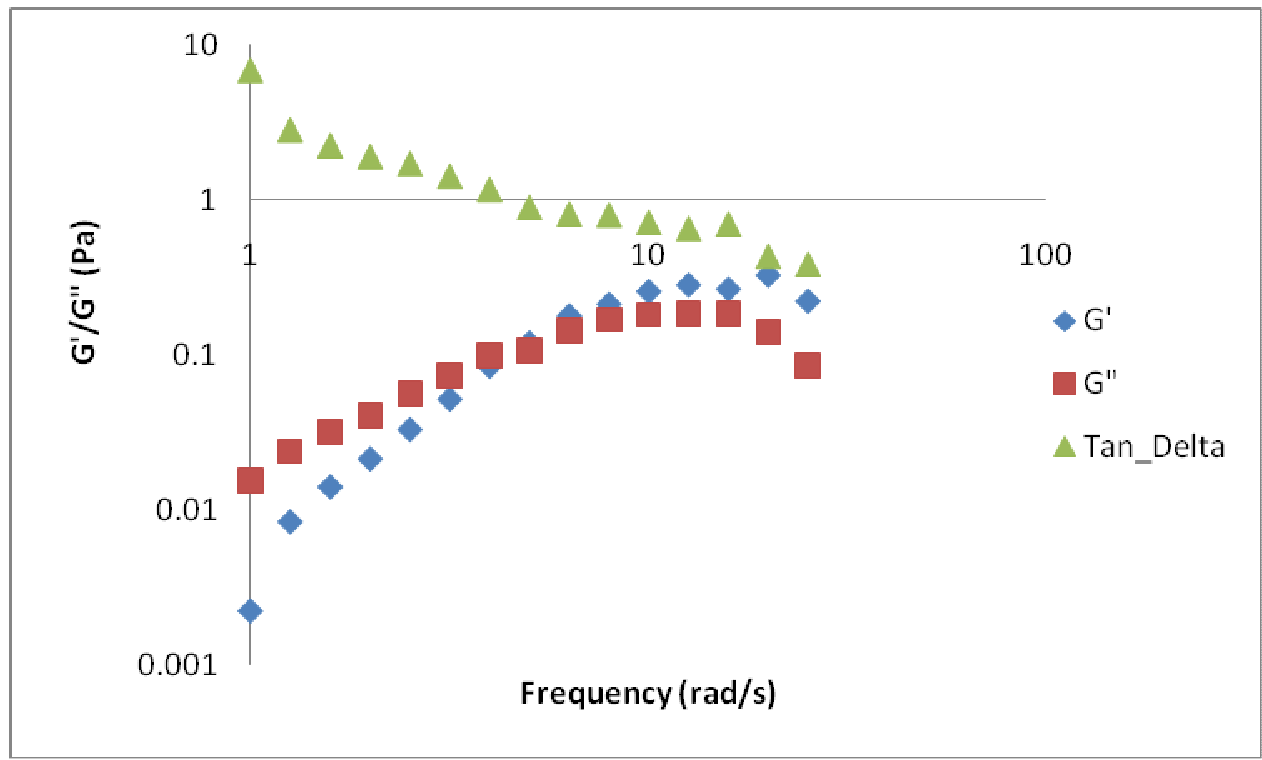


79 Figure 6c

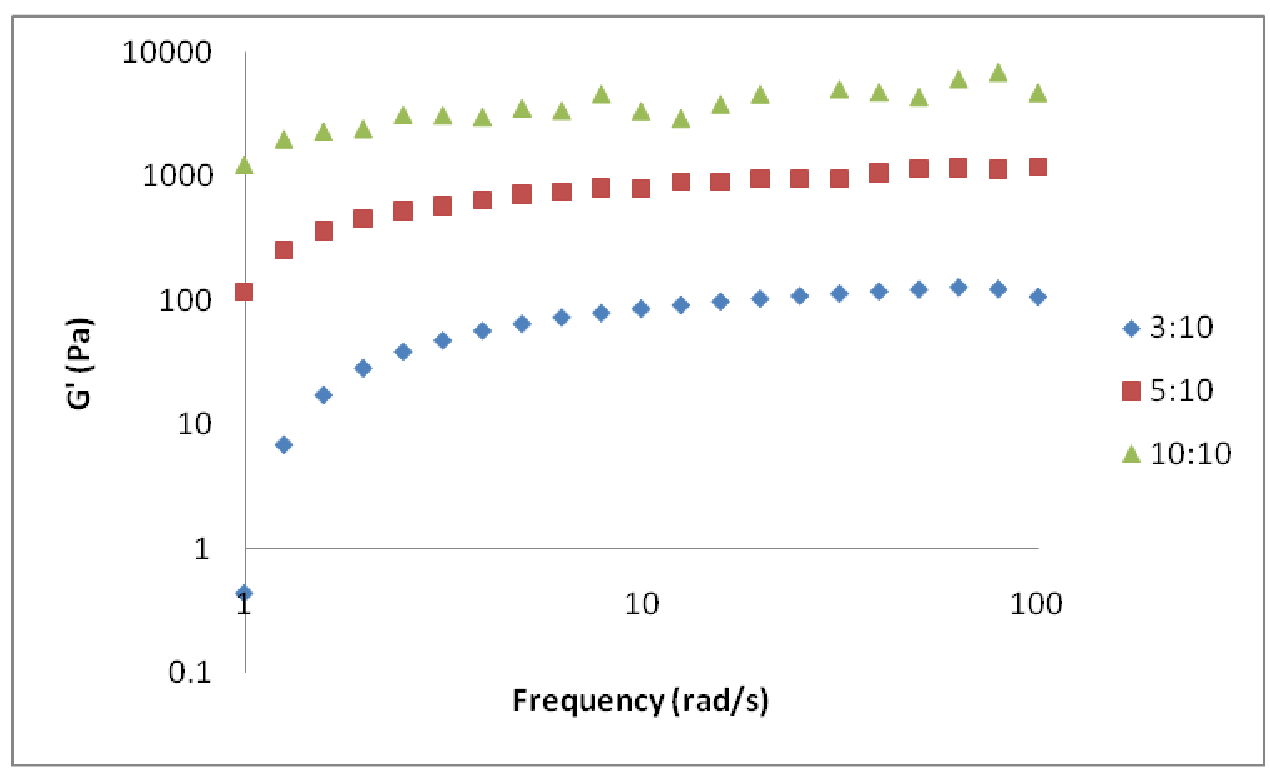

81

82

83

84

85

86

87

Figure 7

88

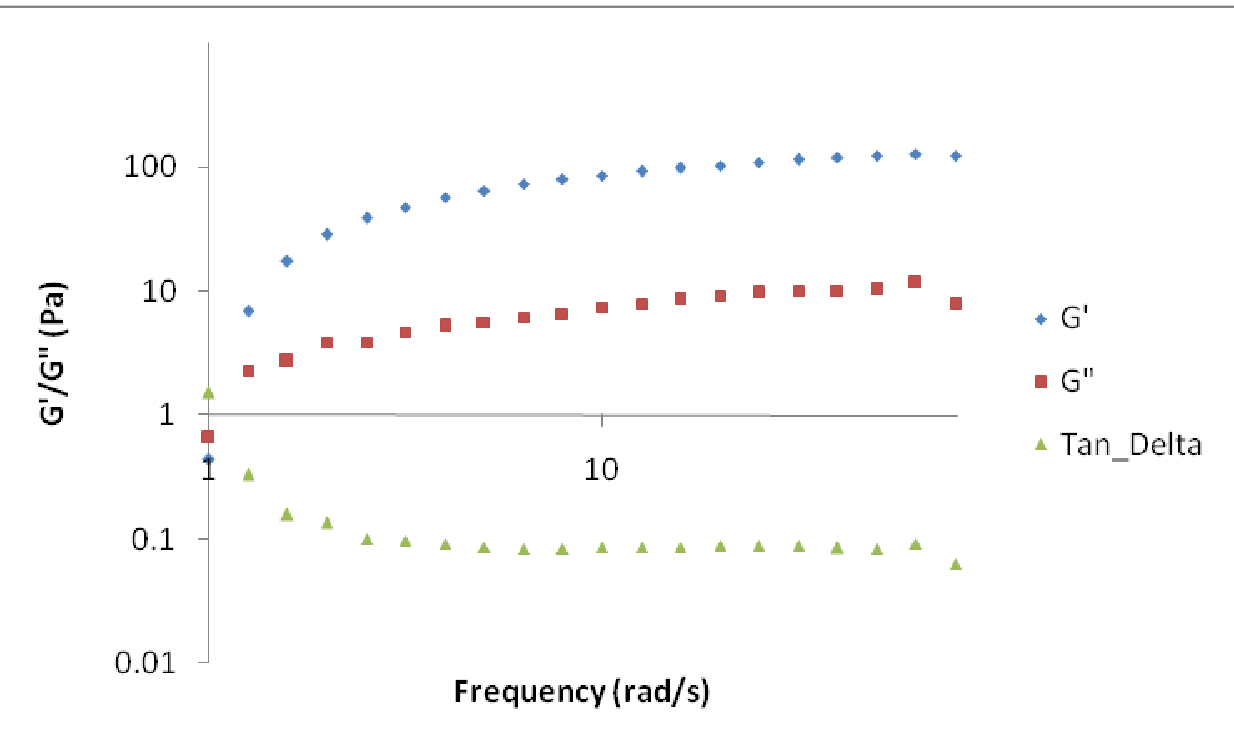


$90 \quad$ Figure 8

91

92

94

95

96

97

98

100

101

102

103

104

105

106

107

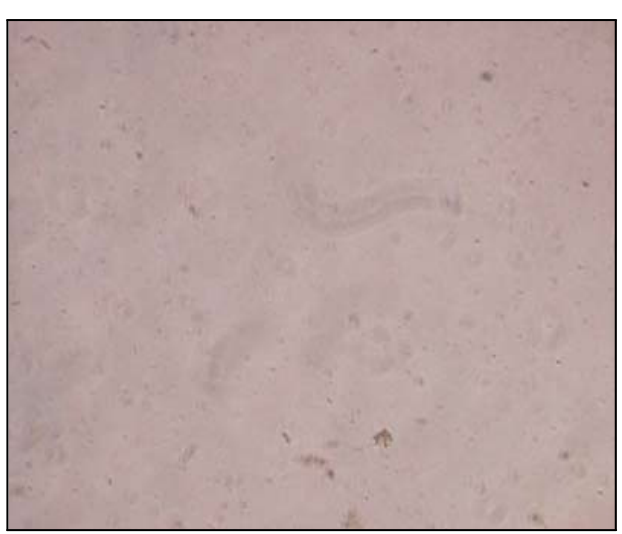

a)

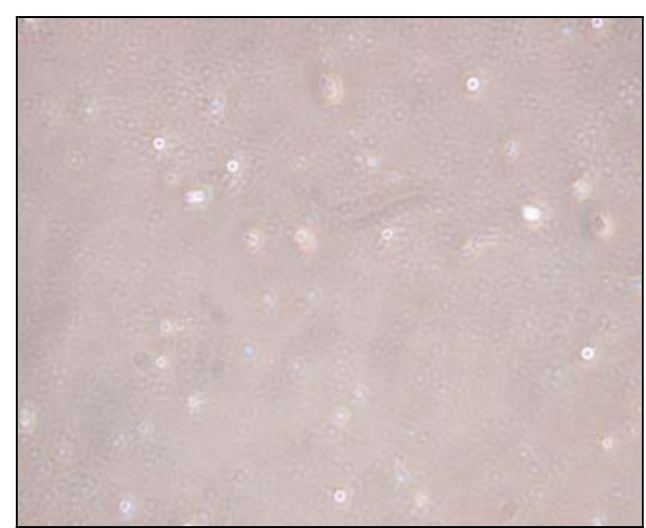

b)

108

109 
110

111

112

113

114

115

116

117

118

119

120

121

122

123

124

125

126

127

128

129

130

131

132

133

134

135

136

137

138

139

140

141

142

143

144

145 a)

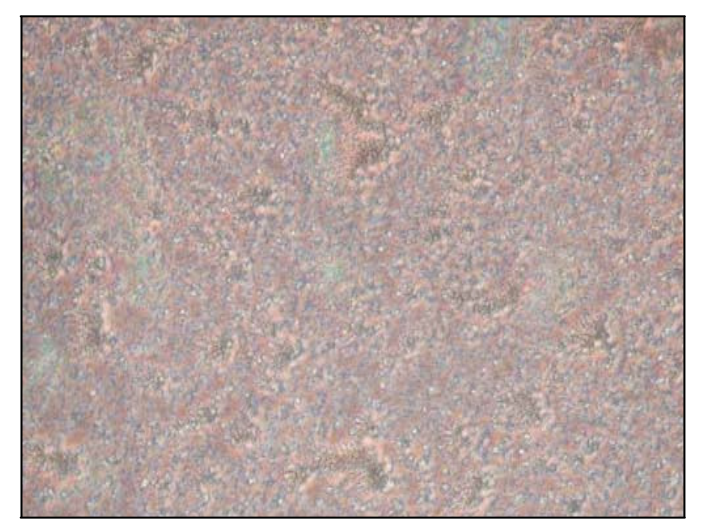

Gelatin: whey, (3:10) b)

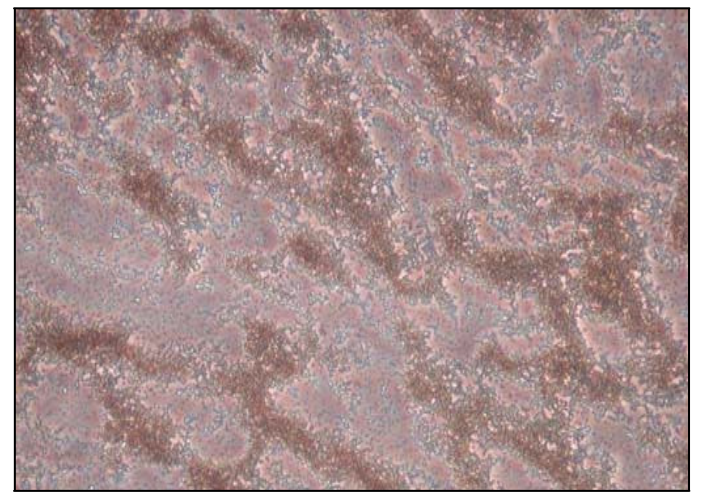

Gelatin: whey, (5:10)

c)

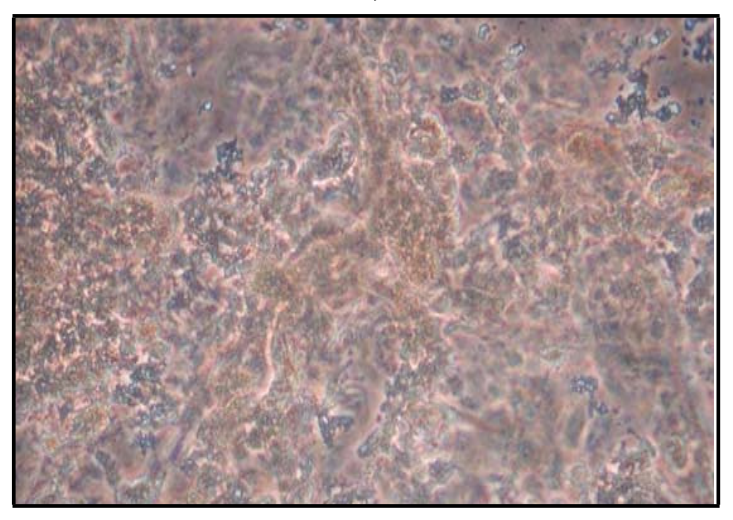

Gelatin: whey, (10:10) 
